\title{
IMPLIKASI TINGKAT KECERDASAN LOGIKA MATEMATIKA SISWA TERHADAP PEMECAHAN MASALAH MATEMATIKA
}

\author{
Kamsari dan Widodo Winarso \\ IAIN Syekh Nurjati Cirebon \\ e-mail: Kamsari2208@gmail.com
}

\begin{abstract}
Abstrak
Penelitian ini bertujuan untuk menyelidiki tingkat kecerdasan logika matematika dan kemampuan pemecahan masalah. Metode penelitian ini adalah studi kasus. Hasil penelitian ini adalah (1) kecerdasan logika matematika siswa kelas 11 IPA SMAN 1 berada pada tingkat kompleks; (2) kemampuan pemecahan masalah pada materi fungsi komposisi dan fungsi invers pada siswa tingkat dasar dan tingkatan kompleks termasuk dalam kategori kurang, dengan rata-rata sebesar 42,75 dan 43,78 , sedangkan siswa tingkatan koheren termasuk dalam kategori baik dengan rata-rata yang diperoleh sebesar 64,24 ; (3) terdapat pengaruh yang signifikan antara kecerdasan logika matematika dengan pemecahan masalah pada materi fungsi komposisi dan fungsi invers sebesar $35,4 \%$ pada tingkat koheren, 12,6\% pada tingkat kompleks dan 6,2\% tingkat dasar; (4) karakteristik setiap tingkat kecerdasan logika matematika dalam memecahkan masalah matematika berbeda-beda. Untuk siswa tingkat dasar dan tingkat kompleks masih lemah pada tahap II dan V, serta baik pada tahap I, III dan IV. Adapun untuk siswa tingkat kohheren sudah cukup baik pada tahap II dan V, serta sangat baik pada tahap I, III dan IV.
\end{abstract}

Kata kunci: Tingkat Kecerdasan, Kecerdasan Logika Matematika, Pemecahan Masalah

\begin{abstract}
The aim of this reseach are to (1) investigate their level of intelligence in mathematical logic and problem-solving abilities. The method of this research was case study. This study showed the following results: (1) the intelligence of mathematical logic of 11th-grade students of Science SMAN 1 is at a complex level; (2) problem-solving skills on compositional function and inverse functions on the elementary and complex level students are included in the category of less, with an average of 42.75 and 43.78 , while the students of the coherent level are included in either category with the average obtained for 64.24; (3) there is a significant influence between the intelligence of mathematical logic and problem solving on the material of compositional function and the inverse function of $35.4 \%$ at the coherent level, $12.6 \%$ at the complex level and $6.2 \%$ of the base rate; (4) the characteristics of each level of mathematical-logical intelligence in solving mathematical problems are different. For elementary and complex level students are still poor at stages II and V, as well as in stages I, III and IV. As for the students, the level of coherence is moderate at stages II and V, as well as excellent at stages I, III and IV.
\end{abstract}

Keywords: Level of Intelligence, Mathematical Logic Intelligence, Problem Solving

\section{PENDAHULUAN}

Pemecahan masalah merupakan salah satu aspek utama dalam tujuan pembelajaran matematika yang diperlukan untuk menerapkan dan mengintegrasikan 
konsep-konsep matematika dan keterampilannya dalam membuat keputusan. Sebagai mata pelajaran, matematika diberikan bukan hanya untuk menghitung angka-angka semata, melainkan juga sebagai sarana dalam memodelkan masalah kehidupan yang kompleks dalam bentuk yang lebih sederhana dengan adanya pelajaran ini, diharapkan siswa dapat memahami lingkungan sekitarnya dalam sudut pandang matematis tadi, sehingga siswa mampu menemukan solusi dari masalah tersebut.

Faktanya, kemampuan siswa dalam memecahkan masalah masih rendah. Hal ini berdasarkan survei yang dilakukan PISA pada tahun 2012 yang menunjukan posisi siswa Indonesia dalam memecahkan masalah pada urutan 64 dari 65 negara yang di survei. Fakta inipun diungkap Kurniawan (2016) dalam penelitiannya yang menyimpulkan bahwa masih rendahnya keterampilan pemecahan masalah pada pembelajaran matematika. Adapun dalam praktiknya, berhasilnya pembelajaran matematika ketika siswa tersebut mampu menyelesaikan masalah yang dihadapinya (Shadiq, 2008). Hal ini menunjukan betapa pentingnya pemecahan masalah pada siswa.

Lemahnya kemampuan siswa dalam memecahkan masalah sendiri mengidentifikasikan adanya kesulitan belajar yang dihadapi oleh siswa. Abdurrahman (2003) menyebutkan dua faktor penyebab kesulitan belajar siswa, yaitu faktor internal dan faktor eksternal. Dari faktor internal, kesulitan belajar dimungkinkan karena adanya gangguan neurologis. Adapun faktor eksternal yang mempengaruhi kesulitan belajar siswa antara lain: strategi pembelajaran yang keliru, pengelolaan kelas yang tidak membangkitkan motivasi belajar, dan penguatan yang tidak tepat. Fuchs, Compton, Fuchs, Paulsen, Bryant \& Hamlett (2005) pun menyebutkan bahwa salah satu penyebab kesulitan belajar siswa dari sisi kondisi permanen yaitu intelegensi yang terbatas.

Kecerdasan logika matematika merupakan kecerdasan yang dimiliki oleh seseorang untuk menganalisis suatu masalah secara logis, memecahkan operasi matematis, dan meneliti suatu masalah secara ilmiah. Kecerdasan logika matematika berkontribusi pada proses pemecahan masalah (Hoerr, Boggeman \& Wallach, 2010). Hanya saja, kebanyakan siswa kurang mengasah kecerdasan logika matematika, sehingga membuat siswa kesulitan dalam memecahkan dan menyelesaikan masalah yang diberikan. Padahal pada dasarnya setiap individu dapat mengembangkan kecerdasan yang dimilikinya (Aziz, 2011). Hal ini bisa saja terjadi karena siswa itu sendiri yang malas untuk mengasahnya, atau juga karena lingkungan sekitarnya yang kurang mendukung bagi siswa untuk mengembangkan kecerdasan tersebut.

Salah satu sekolah yang menerapkan skor kecerdasan sebagai salah satu syarat penjurusannya yaitu SMA Negeri 1 Babakan, yang bertempat di jalan Pangeran Sutajaya No. 4 desa Karangwangun, Kecamatan Babakan Kabupaten Cirebon. Selain itu, SMA Negeri 1 Babakan dianggap sebagai salah satu sekolah terbaik di wilayah timur Cirebon 
berdasarkan akreditasinya (Suhairin, 2016). Hal ini dapat dilihat pula dari prestasi yang kerap di raih oleh siswanya di tingkat kabupaten bahkan provinsi. Tahun 2015, SMA Negeri 1 Babakan mencatatkan nama siswanya sebagai peraih ujian nasioanal (UN) tertinggi se-kabupaten Cirebon (Sonia, 2015). Tahun berikutnya, SMA Negeri 1 Babakan berhasil mencatakan siswanya masuk sebagai 6 besar peraih UN tertinggi di kabupaten Cirebon (Nawawi, 2016). Berbagai prestasi di bidang akademik tersebut tidak serta merta mampu mendeskripsikan keadaan siswa seutuhnya mengenai kemampuan siswanya dalam memecahkan masalah matematis.

Perkembangan teknologi belakangan ini, memberikan ruang yang luas bagi siswa untuk mengeksplor kemampuannya. Pengembangan diri ini diperlukan siswa agar lebih mandiri lagi dalam menyikapi masalah yang dihadapi, terutama permasalahan dalam bentuk soal-soal di sekolah, sehingga siswa mampu memaksimalkan kemampuannya yang terbatas tersebut dengan mengaitkannya pada masalah tersebut. Oleh karena itu, diperlukan penguatan kecerdasan yang dimiliki siswa, terutama kecerdasan logika matematika, karena kecerdasan ini berkaitan dengan kemampuan berhitung dan analisis. Dengan adanya penguatan tersebut, siswa mampu untuk mengenali masalah yang dihadapi serta menafsirkan masalah tersebut.

\section{METODE}

Penelitian ini merupakan penelitian studi kasus yaitu metode penelitian yang digunakan untuk mencari pengaruh perlakuan tertentu terhadap yang lain dalam kondisi yang terkendalikan (Sugiyono, 2012), dengan menggunakan pendekatan mix-methode kuantitatif-kualitatif. Adapun desain penelitiannya adalah Ex Post Facto Design karena tidak ada perlakuan terhadap variabel bebasnya, dengan menggunakan teknik disproportional stratified sampling, yaitu cara pengambilan sampling yang dilakukan dengan menyeleksi setiap unit sampling yang sesuai dengan ukuran unit sampling namun tidak proporsional terhadap ukuran unit sampling karena untuk pertimbangan analisis dan kesesuaian (Sarwono, 2006).

\section{HASIL DAN PEMBAHASAN}

Logika matematika memiliki pengaruh yang positif dan signifikan terhadap pemecahan masalah matematika siswa pada materi Berdasarkan hasil tes kecerdasan logika matematika yang suda dikonversi dengan Standar 9, maka diperoleh data tingkatan kecerdasan logika matematika ditampilkan dalam Tabel 1. 
Tabel 1. Pengelompokan Tingkat Kecerdasan

\begin{tabular}{ccccc}
\hline Standar 9 & Interval & Frekuensi & Kategori & Jumlah \\
\hline 1 & $\ldots \ldots .-44,29$ & 13 & Basic Level & 22 \\
2 & $44,30-49,09$ & 4 & & \\
3 & $49,10-53,89$ & 5 & Complex Level & 45 \\
4 & $53,90-58,69$ & 22 & & \\
5 & $58,70-63,49$ & 15 & & 33 \\
6 & $63,50-68,29$ & 8 & & \\
7 & $68,30-73,09$ & 16 & & \\
8 & $73,10-77,89$ & 15 & & 100 \\
9 & $77,90-\ldots \ldots \ldots$ & 2 & & \\
\hline
\end{tabular}

Berdasarkan Tabel 1 diketahui bahwa 22 responden tergolong dalam tingkatan dasar, 45 responden tergolong dalam tingkatan kompleks dan 33 responden termasuk dalam tingkatan koheren. Adapun gambaran secara umum mengenai kecerdasan logika matematika siswa kelas 11 IPA SMA Negeri 1 Babakan termasuk dalam tingkatan sebanyak kompleks, yaitu berada pada interval 58,70 - 63,49 dengan rata-rata 61,09.

Hasil tes kemampuan siswa dalam pemecahan masalah pada materi fungsi komposisi dan fungsi invers kelas 11 IPA SMA Negeri 1 Babakan yang berada pada tingkatan dasar termasuk dalam kategori kurang dengan rata-rata 42,73. Untuk siswa yang berada pada tingkatan kompleks termasuk dalam kategori kurang dengan rata-rata 43,78. Adapun untuk siswa yang berada pada tingkatan koheren termasuk dalam kategori cukup baik dengan rata-rata 62,24 . Sedangkan untuk proses siswa dalam penjawaban tes pemecahan masalah ditampilkan dalam Tabel 2, Tabel 3, Tabel 4, Tabel 5, dan Tabel 6.

Tabel 2. Kemampuan Siswa dalam Membaca dan Berpikir

\begin{tabular}{|c|c|c|c|c|c|}
\hline \multirow{2}{*}{$\begin{array}{l}\text { Tingkat Kecerdasan Logika } \\
\text { Matematika }\end{array}$} & \multicolumn{3}{|c|}{ Soal } & \multirow{2}{*}{ Jumlah } & \multirow{2}{*}{ Persentase (\%) } \\
\hline & 1 & 2 & 3 & & \\
\hline Tingkat Dasar & 17 & 14 & 14 & 45 & 68,18 \\
\hline Tingkat Kompleks & 44 & 41 & 29 & 114 & 84,44 \\
\hline Tingkat Koheren & 33 & 32 & 31 & 96 & 96,70 \\
\hline
\end{tabular}


Tabel 3. Kemampuan Siswa dalam Mengeksplorasi dan Merencanakan

\begin{tabular}{lccccc}
\hline Tingkat Kecerdasan Logika & \multicolumn{3}{c}{ Soal } & \multirow{2}{*}{ Jumlah } & Persentase (\%) \\
\cline { 2 - 4 } Matematika & 1 & 2 & 3 & & 15 \\
\hline Tingkat Dasar & 5 & 0 & 10 & & 22,72 \\
Tingkat Kompleks & 13 & 1 & 13 & 27 & 20 \\
Tingkat Koheren & 18 & 2 & 16 & 32 & 32,32 \\
\hline
\end{tabular}

Tabel 4. Kemampuan Siswa dalam Memilih Strategi

\begin{tabular}{lccccc}
\hline Tingkat Kecerdasan Logika & \multicolumn{3}{c}{ Soal } & \multirow{2}{*}{ Jumlah } & Persentase (\%) \\
\cline { 2 - 4 } Matematika & 1 & 2 & 3 & & \\
\hline Tingkat Dasar & 13 & 11 & 10 & 34 & 51,51 \\
Tingkat Kompleks & 22 & 15 & 13 & 50 & 37,04 \\
Tingkat Koheren & 24 & 9 & 16 & 59 & 59,60 \\
\hline
\end{tabular}

Tabel 5. Kemampuan Siswa dalam Mencari Jawaban

\begin{tabular}{lccccc}
\hline Tingkat Kecerdasan Logika & \multicolumn{3}{c}{ Soal } & \multirow{2}{*}{ Jumlah } & Persentase (\%) \\
\cline { 2 - 4 } Matematika & 1 & 2 & 3 & & \\
\hline Tingkat Dasar & 13 & 6 & 14 & 43 & 65,15 \\
Tingkat Kompleks & 35 & 28 & 27 & 80 & 59,26 \\
Tingkat Koheren & 33 & 32 & 31 & 96 & 69,70 \\
\hline
\end{tabular}

Tabel 6. Kemampuan Siswa dalam Merefleksi dan Mengembangkan

\begin{tabular}{lccccc}
\hline Tingkat Kecerdasan Logika & \multicolumn{3}{c}{ Soal } & \multirow{2}{*}{ Jumlah } & Persentase (\%) \\
\cline { 2 - 4 } Matematika & 1 & 2 & 3 & & \\
\hline Tingkat Dasar & 7 & 0 & 7 & 14 & 21,21 \\
Tingkat Kompleks & 12 & 1 & 8 & 21 & 15,56 \\
Tingkat Koheren & 17 & 1 & 23 & 41 & 41,41 \\
\hline
\end{tabular}

Berdasarkan tabel di atas diperoleh hasil bahwa kemampuan siswa dalam proses pemecahan masalah masih rendah pada tahap mengeksplorasi dan merencanakan serta merefleksi dan mengembangkan untuk setiap tingkat kecerdasan. Sebaliknya pada tahap membaca dan berpikir, memilih strategi, dan mencari jawaban sudah baik.

SMA Negeri 1 Babakan merupakan salah satu sekolah dengan predikat $A$ di wilayah timur Kabupaten Cirebon. Hal ini dapat terlihat dari prestasi yang ditorehkan baik akademik maupun non-akademik. Selain itu, SMA Negeri 1 Babakan di dukung pula oleh guru-guru yang profesional dibidangnya. Berbagai sarana prasarana pun tersedia demi membantu siswa dalam pembelajaran. Sehingga keterkaitan semua komponen tersebut 
saling bersinergi satu dengan yang lainnya dalam memaksimalkan hasil belajar siswa, salah satunya kemampuan pemecahan masalahnya dan juga kecerdasan siswa.

Kecerdasan logika matematika merupakan kecerdasan dalam hal matematis dan logika. Kecerdasan logika matematika berkaitan dengan dan mencakup kemampuan ilmiah, baik dalam hal menganalisa suatu masalah maupun dalam memecahkan suatu operasi matematis (Gardner, 1999). Lazear (1991) mengelompokan kecerdasan logika mateamatika ke dalam tiga tingkatan, yaitu tingkatan koheren, tingkatan kompleks dan tingkatan dasar. Dalam mempelajari, memahami dan memecahkan masalah yang berkaitan dengan materi fungsi komposisi dan fungsi invers pada mata pelajaran matematika, tentunya akan melibatkan kecerdasan jenis ini. Fungsi komposisi dan fungsi invers dirasa sulit oleh sebagian siswa, karena selain banyak menggunakan angka-angka dalam penjelasannya, dibutuhkan pula penalaran yang logis. Tentunya dalam mempelajari dan memecahkan masalah yang berkaitan dengan fungsi komposisi dan fungsi invers, setiap tingkatan dalam kecerdasan ini memiliki karakteristik tersendiri antara siswa yang berada di tingkatan yang satu dengan tingkatan yang lainnya.

Adapun kemampuan siswa dalam memecahkan masalah matematika berdasarkan Krulik \& Rudnick (1995), setiap tingkatan kecerdasan memiliki perbedaan dalam proses penjawabannya. Untuk tingkat dasar, sebanyak 68,18 \% siswa mampu pada tahap I, 22,72 \% pada tahap II, 51,51 \% pada tahap III, 65,15 \% pada tahap IV dan 27,27 \% pada tahap V. Untuk tingkat Kompleks, 84,44 \% siswa mampu pada tahap I, $20 \%$ pada tahap II, 37,04 \% pada tahap III, 59,26 \% pada tahap IV dan 15,56 \% pada tahap V. Untuk tingkat koheren, sebanyak 96,97 \% siswa mampu pada tahap I, 32,32 \% pada tahap II, 59,60 \% pada tahap III, 96,97 \% pada tahap IV dan $41,41 \%$ pada tahap V.

Hasil pengujian hipotesis antara siswa yang berada di tingkatan dasar diperoleh persamaan regresi, $Y=42,500+1,278 D_{2}+21,742 D_{3}$. Angka-angka ini dapat ditafsirkan sebagai berikut: (1) Konstanta sebesar 43,778, artinya jika kecerdasan logika matematika yang berada pada tingkatan kompleks $\left(D_{2}\right)$ bernilai 0 dan siswa yang berada pada tingkatan koheren $\left(D_{3}\right)$ bernilai 0 , maka kemampuan siswa dalam melakukan pemecahan masalah pada materi fungsi komposisi dan fungsi invers pada mata pelajaran matematika (Y) nilainya sebesar 42,500, sehingga konstanta tersebut dapat menjelaskan bahwa siswa tersebut berada pada tingkat kecerdasan dasar. (2) Koefisien regresi variabel harga $\left(D_{2}\right)$ sebesar 1,278, artinya jika nilai kecerdasan logika matematika siswa yang berada di tingkat kompleks meningkat 1 dan variabel harga $\left(D_{3}\right)$ bernilai 0 , maka kemampuan siswa dengan tingkat kecerdasan kompleks dalam memecahkan masalah fungsi komposisi dan fungsi invers pada mata pelajaran matematika (Y) akan mengalami kenaikan sebesar 1,262; (3) Koefisien regresi variabel harga $\left(D_{3}\right)$ sebesar 21,742 , artinya jika nilai kecerdasan logika matematika siswa yang berada di tingkat koheren meningkat 1 dan 
variabel harga $\left(D_{2}\right)$ bernilai 0 , maka kemampuan siswa dengan tingkat kecerdasan koheren dalam memecahkan masalah fungsi komposisi dan fungsi invers pada mata pelajaran matematika $(Y)$ akan mengalami kenaikan sebesar 21,742.

Koefisien bernilai positif artinya terjadi hubungan yang positif antara kecerdasan logika matematika siswa yang berada di tingkat dasar, tingkat kompleks dan tingkat koheren dengan pemecahan masalah pada materi fungsi komposisi dan fungsi invers mata pelajaran matematika, semakin siswa meningkatkan kecerdasan logika matematika mereka maka kemampuan pemecahan masalah pada materi fungsi komposisi dan fungsi invers mata pelajaran matematika akan turut meninngkat. Untuk mengetahui kelayakan asumsi bahwa kecerdasan logika matematika di tiap tingkatannya berpengaruh terhadap pemecahan masalah matematika siswa pada materi fungsi komposisi dan fungsi invers di kelas 11 IPA SMA Negeri 1 Babakan, dengan cara membandingkan $F_{\text {reg }}$ dengan $F_{\text {tabel }}$ dan juga dengan membandingkan prob.F hitung (Sig.) dengan taraf signifikansinya. Jika $F_{\text {reg }}>$ $F_{\text {tabel }}$ dan prob. F hitung (Sig.)< taraf signifikansinya, maka asumsi tersebut layak digunakan. Jika sebaliknya $F_{\text {reg }}<F_{\text {tabel }}$ dan prob. $F$ hitung (Sig.) $>$ taraf signifikansinya, maka asumsi tersebut tidak layak digunakan.

Hasil analisis uji hipotesis, dengan menggunakan taraf signifikansi $5 \%$ dan $1 \%$ diperoleh prob. F hitung (Sig.) untuk tingkat kecerdasan logika matematika sebesar 0,000, adapun nilai $F_{\text {reg }}$ untuk tingkat kecerdasan logika matematika dengan db 3 dan df 97 diperoleh $F_{\text {reg }}$ sebesar 26,714 dengan $F_{\text {tabel }}$ sebesar 2,70 pada taraf $5 \%$ dan 3,99 pada taraf $1 \%$, maka $F_{\text {reg }} 26,714>F_{\text {tabel }} 2,70$ dan $F_{\text {reg }} 26,714>F_{\text {tabel }} 3,99$. Berdasarkan perbandingan tersebut di dapat hasil yang signifikan, yang berarti hasil tersebut tidak hanya berlaku pada sampel tetapi juga pada populasi, sehingga dapat disimpulkan bahwa tingkat kecerdasan logika matematika berpengaruh terhadap kemampuan siswa dalam pemecahan masalah pada materi fungsi komposisi dan fungsi invers mata pelajaran matematika di kelas 11 IPA SMA Negeri 1 Babakan.

Hasil uji korelasi product moment diperoleh $r_{x y}=0,596>0,195 r_{\text {tabel }}(0,05), r_{x y}=$ $0,596>0,256 r_{\text {tabel }}(0,01)$, maka antar variabel tersebut terjadi korelasi yang positif. Dengan demikian diketahui adanya hubungan yang positif antara tingkat kecerdasan logika matematika terhadap pemecahan masalah matematika siswa pada materi fungsi komposisi dan fungsi invers di kelas 11 IPA SMA Negeri 1 Babakan. Selain itu, berdasarkan kriteria korelasi, angka $r_{x y}=0,596$ termasuk kategori korelasi kuat, sehingga dapat disimpulkan bahwa kenaikan kemampuan siswa dalam memecahkan masalah sangat berhubungan dengan peningkatan keerddadsan logika matematikanya. Setelah diadakan uji hipotesis dengan thitung sebagaimana di atas maka hasil yang dipeoleh dikonsultasikan dengan $t_{\text {tabel }}$ dan diketahui bahwa $t_{3 h i t u n g}=7,333>1,661 t_{\text {tabel }}(0,05) d i$ tingkat koheren, $t_{2 \text { hitung }}=-3,757>1,661 t_{\text {tabel }}(0,05)$ di tingkat kompleks, dan $t_{1 \text { hitung }}=-2,550$ 
$>1,661 t_{\text {tabel }}(0,05)$ di tingkat dasar, sehingga pengaruh tingkat kecerdasan logika matematika terhadap pemecahan masalah matematika siswa pada materi fungsi komposisi dan fungsi invers di kelas 11 IPA SMA Negeri 1 Babakan adalah signifikan.

Koefisien determinasi yang dihasilkan untuk tingkat kecerdasan logika matematika $r^{2}=0,342$. Hal ini menjelaskan bahwa dalam memecahkan masalah pada materi fungsi komposisi dan fungsi invers, tingkat kecerdasan logika matematika berpengaruh sebesar $34,2 \%$ yang diberikan melalui persamaan $Y=42,500+1,278 D_{1}+21,742 D_{3}$ dengan sisanya sebesar $65,8 \%$ dipengaruhi oleh faktor lain. Kecilnya faktor kecerdasan logika matematika terhadap pemecahan masalah yang dihadapi siswa dapat dijelaskan berdasarkan observasi yang dilakukan. Dari proses pembelajaran yang berlangsung di kelas, didapati adanya komunikasi yang kurang antara guru dan siswa. Hal ini dapat terlihat dari rendahnya keaktifan siswa selama proses pembelajaran. Adapun dari proses keaktifan siswa dalam hal memperhatikan, didapati sebagian kecil siswa mengobrol saat guru sedang menjelaskan, sedangkan sisanya ada yang memperhatikan dan ada pula yang diam. Dalam menyesaikan masalah yang diberikan guru, sebagian besar siswa mendiskusikannya dengan teman sebangkunya. Kelompok pun cenderung homogen.

Keberhasilan siswa dalam memecahkan masalah tak lepas dari faktor guru. Guru dalam pembelajaran memliki peranan yang sentral. Berdasarkan hasil observasi, didapati kurangnya komunikasi antara siswa dengan guru selama proses pembelajaran berlangsung. Selain itu, soal-soal yang diberikan hanya bersifat teoritis, sehingga kurangnya pembiasaan siswa terhadap soal-soal yeng bersifat pemecahan masalah. Selain itu, gaya belajar siswapun turut berpengaruh terhadap kemampuan siswa dalam memecahkan masalah (Widiyanti, 2011).

\section{SIMPULAN}

Berdasarkan hasil analisis data dan pembahasan dapat diambil kesimpulan sebagai berikut: (1) Kecerdasan logika matematika siswa kelas 11 IPA SMA Negeri 1 Babakan $45 \%$ berada pada tingkatan kompleks, $22 \%$ berada pada tingkatan dasar dan $33 \%$ berada pada tingkatan koheren, dengan nilai rata-rata tes kecerdasan logika matematika sebesar 61,09; (2) Kemampuan pemecahan masalah siswa pada materi fungsi komposisi dan fungsi invers untuk kecerdasan logika matematika pada tingkatan dasar dan kompleks termasuk dalam kategori kurang, dengan diperoleh rata-rata hasil tes sebesar 42,75 untuk tingkatan dasar dan 43,78 untuk tingkatan kompleks, sedangkan untuk siswa dengan tingkat koheren termasuk dalam kategori baik dengan diperoleh dari tes sebesar 64,24; (3) Terdapat pengaruh yang signifikan antara tingkat kecerdasan logika matematika dengan kemampuan siswa dalam memecakan masalah pada materi fungsi komposisi dan fungsi invers mata pelajaran matematika di kelas 11 IPA SMA Negeri 1 Babakan sebesar 
$34,2 \%$ dan untuk sisanya sebesar $65,8 \%$ dipengaruh oleh faktor lain seperti kompetensi guru, gaya belajar, lingkungan belajar dan kurangnya siswa dalam berlatih soal-soal pemecahan masalah.

\section{DAFTAR PUSTAKA}

Abdurrahman, M. 2003. Pendidikan Bagi Anak Berkesulitan Belajar. Jakarta: Rineka Cipta.

Fuchs, L. S., Compton, D. L., Fuchs, D., Paulsen, K., Bryant, J. D., \& Hamlett, C. L. (2005). The Prevention, Identification, and Cognitive Determinants of Math Difficulty. Journal of Educational Psychology, 97(3): 493-513.

Gardner, H. 1999. Inteligence Reframed: Multiple Intelligence for the 21st Century. New York: Basic Books.

Hoerr, T. R., Boggeman, S., \& Wallach, C. (2010). Celebrating every learner: Activities and strategies for creating a multiple intelligences classroom. John Wiley \& Sons.

Krulik, S., \& Rudnick, J. A. 1995. The New Sourcebook for Teaching Reasoning and Problem Solving in Elementary School. A Longwood Professional Book. Allyn \& Bacon, 111 Tenth St., Des Moines, IA 50309.

Kurniawan, H. 2016. Analisis Keterampilan Pemecahan Masalah Pada Pembelajaran Matematika. Prosiding IImu Pendidikan, 1(2):.67-73.

Nawawi. 2016. Lulusan SMAN Babakan Banyak Diterima Perguruan Tinggi Favorit. Fajar News.

Sarwono, J. (2006). Metode Penelitian Kuantitatif \& Kualitatif. Yogyakarta: Graha IImu.

Shadiq, F. (2008). Logika Matematika dan Pemecahan Masalah dalam Pembelajaran Matematika SMA. Yogyakarta: Pusat Pengembangan dan Pemberdayaan Pendidik dan Tenaga Kependidikan Matematika.

Sonia, R. 2015. Ini Siswa yang Mendapatkan Nilai UN Tertinggi di Kabupaten Cirebon. Cirrebon Trust. Diambil kembali dari Cirebon Trust.

Sugiyono. 2012. Metode Penelitian Pendidikan. Bandung: Alfabeta.

Suhairin. 2016. SMAN 1 Babakan. Retrieved from Sekolah Kita - Kemdikbud: http://sekolah.data.kemdikbud.go.id/index.php/chome/profil/ba393d70-146b-49d6ac56-19c432f32c77.

Lazear, D. 1991. Seven ways of knowing: Understanding multiple intelligences. Palatine, IL: Skylight.

Widiyanti, T. (2011). Pengaruh gaya belajar terhadap kemampuan pemecahan masalah matematika. Skripsi. Jakarta: UIN Syarif Hidayatullah 